This is the peer reviewed version of the following article:

Grappi, S., Romani, S., Barbarossa, C. (forthcoming). "Fashion without pollution: How consumers evaluate brands after an NGO campaign aimed at reducing toxic chemicals in the fashion industry", Journal of Cleaner Production. DOI: 10.1016/j.jclepro.2017.02.183

available at: http://www.sciencedirect.com/science/article/pii/S0959652617304092

This article may be used for non-commercial purposes in accordance Elsevier terms and conditions for selfarchiving.

\title{
Fashion without pollution: How consumers evaluate brands after an NGO campaign aimed at reducing toxic chemicals in the fashion industry
}

Abstract

This research analyzes the effects on consumer responses of an NGO campaign (Greenpeace's 2011 Detox campaign), aimed at reducing toxic chemicals in the manufacturing processes and final products of fashion brands. The proposed model explains and tests the mechanisms underlying negative consumer reactions to the fashion brands that are the focus of NGO campaigns. The findings illustrate the mediating role that consumers' evaluations of brand blame play in their attitude towards such brands and subsequent purchase intentions. Two relevant moderators - (1) consumer reasons for justifying brands' unethical behavior in the market and (2) the decision of certain brands to comply with the NGO campaign's requests - play a significant part in the mediation mechanism. These findings make original contributions to theory and have important implications for consumers, companies, and NGOs, because they provide fresh insights into understanding, and handling effectively, consumer reactions to NGO campaigns aimed at reducing the use of toxic chemicals in the fashion industry.

Keywords: toxic chemical reduction, Detox campaign, brand blame, consumer attitude towards brands, consumer reasons for justifying brands' unethical behavior, brand compliance with NGO campaign. 


\section{Introduction}

Recent research shows that an increasing number of consumers take the "politics behind the products" (Micheletti, 2003) into account when they make purchase decisions (Sassatelli, 2006; Stolle and Micheletti, 2013), and that these decisions are driven by moral rationale and pro-environmental motivation (Hoffmann and Hutter, 2012; Klein et al., 2004). Research also points out that people's consumption behavior - the result of the consumer's individual evaluation of, or of his/her exposure to, such collective stimuli as those provided by the campaigns of non-governmental organizations (NGOs) - plays an increasingly important role in developing more sustainable and responsible business practices in the market (Lorek and Spangenberg, 2014; Mont and Plepys, 2008).

Scholars have extensively addressed the subject of individual consumer responses to a company's behavior (Chatzidakis and Lee, 2013), such as decisions to punish (i.e., to boycott) or reward (i.e., to buycott) companies for their irresponsible or irreproachable conduct (Balsiger, 2010; Forno and Caccarini, 2006). The analysis of consumer behavior after the consumer has been exposed to collective stimuli — which may incite consumers to consider ethical and environmental issues when making their consumption choices — has received less attention. Collective actors and institutions attempt to guide consumer evaluations and practices by charging them with moral significance (Den Hond and De Bakker, 2007). NGOs play a pivotal role in this regard, because they may use the consumer's choices to achieve ethical, social, and environmental changes (Balsiger, 2014; O'Rourke, 2005). Hence any research into socially responsible consumer behavior should carefully appraise the effects of consumers' exposure to the stimuli that organizations provide (e.g., NGO campaigns).

The fashion industry provides a suitable context for analyzing consumer reactions to a company's unethical behavior, especially if the stimuli of independent organizations, concerned with changing fashion brand practices, are directed at the consumer. In the vast landscape of fashion there is a growing sense that "eco" and "ethical" fashion is not an option for shoppers with a conscience (The 
Guardian, 2013). According to The Guardian (2011), consumers believe that many of the world's biggest fashion houses pay virtually no attention to corporate ethics, and NGOs increasingly demand that fashion brands take responsibility for their operations. In 2012, five NGOs (IPE, Friends of Nature, Green Beagle, Envirofriends, and Nanjing Greenstone) launched the "Cleaning up the Fashion Industry" campaign, which denounced forty-eight multinational and domestic fashion brands for using polluting factories in China (Institute of Public \& Environmental Affairs, 2012). Similarly, in 2011, Greenpeace released the "Dirty Laundry" report, exposing hidden links between textile manufacturing facilities in China that discharge hazardous chemicals into the water, and several international leading brands (Greenpeace, 2011a). As a consequence of this "Detox" campaign (Greenpeace, 2011b), some brands committed themselves to eliminating toxic chemicals from their products and to reducing the environmental footprint of their manufacturing; other brands, however, did not (Greenpeace, 2011b; 2016).

Based on these considerations, this paper investigates the effects that a specific NGO campaign had on consumer responses to brands in the fashion industry. The relevant campaign was Greenpeace's 2011 Detox campaign, which demanded that fashion brands work to reduce the use of toxic chemicals in manufacturing processes and final products. This study answers the question of "how" consumers reacted to the brands involved in the NGO campaign. In so doing, it provides new insights into proenvironmental consumer behavior. Using survey data collected from real consumers, it examines consumers' perceptions as to the severity of the toxic chemical scandal reported by the NGO campaign, and how those perceptions shaped their evaluations of brand blame and subsequent evaluative and behavioral responses toward the faulty brand.

Moreover, to be considered as moderators of the psychological mechanism of blame attribution are such factors as (i) consumer reasons for justifying a brand's unethical behavior and (ii) the brand's compliance with the campaign's requests. Thus by answering the question as to "when" consumers 
react negatively to the brands involved in the NGO campaign, this study provides new insights into the specific circumstances under which the psychological mechanism of blame attribution occurs.

\section{Theoretical framework and development of hypotheses}

\subsection{Consumer reactions towards brands involved in toxic chemical scandals}

In this section we present theoretical foundations for the better understanding of how consumers evaluate and respond to brands involved in such product-harm incidents as toxic chemical scandals. Consumers' evaluations of brands involved in product-harm incidents generally result from blame attributions, namely the process by which consumers spontaneously attribute responsibility to harmful brands (Folkes, 1988). Specifically, this work hypothesizes that consumers' evaluative and behavioral responses towards a brand involved in a toxic chemical scandal are indirectly influenced by their perception of the severity of the scandal, via the mediating role of attribution of blame towards the brand.

Consumer perception of the severity of a toxic chemical scandal can be determined by the degree of physical harm (e.g. potential illness, injury, or death) and financial loss incurred (Laufer et al., 2005). The perceived severity of a toxic chemical incident can therefore be assessed by measuring the differences between observers on how harmful each judges the toxic chemical incident to be. Previous research has shown that the more severe the harmful behavior becomes, the more responsible the harm-doer is held to be. Burger (1981) and Robbennolt (2000) have investigated the effect of outcome severity on responsibility attributions using the technique of meta-analysis, and have found a positive relationship between the consumer's perceived severity of the harmful behavior and his/her responsibility attributions (Gao et al., 2013).

This empirical evidence is grounded in psychological theories such as defensive attribution

hypothesis (Walster, 1966) and non-motivational theory (Brewer, 1977). As regards defensive attribution hypothesis, Walster (1966) explains that, as the consequences of an action become more 
severe, observers find it increasingly frightening to recognize that such an outcome might possibly befall them. Hence, in order to cherish their belief that they can avoid a similar fate, observers increasingly attribute responsibility for the occurrence to the harm-doer. On the other hand, nonmotivational explanations (Brewer, 1977) suggest that because incidents with mild outcomes occur more often than do incidents with more severe outcomes, observers do not associate mild accidents with specific individuals. Thus, observers assign less responsibility to an actor when the outcome is mild because similar incidents occur frequently to individuals. By contrast, "the relative rarity of severe accidents leads the observer to associate the event with the specific behavior and characteristics of the perpetrator" (DeJoy and Klippel, 1984, p. 113). Accordingly, more responsibility is attributed to an actor under particularly severe circumstances.

Consumer evaluation of brand blame is defined as the degree to which consumers perceive the brand to be responsible, accountable, and blameworthy for the toxic chemical scandal reported by the NGO's campaign (Klein and Dawar, 2004). Consumer attribution of blame towards a company involved in such a product-harm crisis affects consumer evaluations of, and behavior towards, the faulty company. The theory of cognitive dissonance (Festinger, 1957) corroborates this notion. Individuals seek to maintain congruity between thoughts, evaluations and actions, and strive for internal consistency. An individual who experiences inconsistency tends to become psychologically uncomfortable, and is motivated to try to reduce this dissonance through his or her behavior (Festinger, 1957). Hence, when individuals perceive that a brand is responsible and blameworthy for a toxic chemical scandal, they tend to develop negative predispositions and to engage in negative behavior towards the faulty brand. On the whole, these studies corroborate the hypothesis that the more consumers perceive the toxic chemical scandal as profoundly severe, dangerous, and harmful, the more likely they are to attribute responsibility to the agent company and blame it for the toxic chemical incident. 
Empirical findings provide compelling evidence that consumers' judgment of culpability affects their attitudes and consumer behavior. Jorgensen (1994) applies Weiner's (1986) model of consumer attributions in the context of serious company disasters, and finds that those attributions as to the cause of the disasters change the consumers' attitudes to the company. Verbeke (2001) finds similar results concerning consumer attitudes to fresh meat after the Belgian dioxin crisis. Several studies examine how consumers' negative judgments influence their further evaluations of a brand (Smith and Bolton, 2002). Hence, blame is supposed to negatively affect attitude - i.e., consumers' favorable predispositions - towards a brand involved in a toxic chemical scandal reported by an NGO campaign. Brand attitude then, we may logically conclude, affects consumers' behavioral responses such as their intentions as to whether or not to purchase the faulty brand in the future. Folkes (1988) and Lin et al. (2011) show that blame attributions lead to the desire to complain, and thus affect repurchase behavior. Klein and Dawar (2004) report that the effects of attributions can change brand evaluations, which, in turn, affect behavioral buying intentions. On the whole, these studies corroborate the hypothesis that the more consumers blame the company for the toxic chemical scandal reported by the NGO's campaign, the less they develop positive attitudes towards the faulty brand, and the less they are willing to purchase it in the near future.

Based on the theory reviewed above, we hypothesize that (see Figure 1):

H1: Consumers' perceptions of the severity of the toxic chemical scandal reported by the NGO's campaign affect consumers' attitude towards the faulty brand via the mediating role of consumers' attribution of blame to the brand. That is, the stronger the effect of the severity of the toxic chemical scandal reported by the NGO's campaign, the greater the attribution of blame to the brand and, accordingly, the greater the negative effect on attitudes towards the brand. 
H2: The consumers' attitude towards the faulty brand influences their intentions to purchase the faulty brand in the near future.

\subsection{The moderating effect of consumer reasons for justifying a brand's unethical behavior}

The process of blame attribution may vary according to different consumer characteristics (i.e., consumer reasons for justifying brands' unethical behavior, d'Astous and Legendre, 2009; Eckhardt et al., 2010) ${ }^{1}$ and external factors (i.e., a brand's compliance with the NGO's campaign, Brennan and Merkl-Davies, 2014; Brennan et al., 2013). These individual characteristics and external factors define the boundary conditions for the hypothesized conceptual model.

Consumers attribute blame on the basis of the information they receive and elaborate concerning a brand's misconduct (i.e., the perceived severity, harm and danger of the effects caused by the toxic chemical incident) (Folkes, 1988; Kelley and Michela, 1980). However, even when clear information is available, consumers can reinterpret this information to suit their opinions and beliefs. In the specific context of this study, consumers' prior beliefs may include the reasons and rationales they have for justifying a company's unethical behavior in the market, such as a brand's use of toxic chemicals in manufacturing processes and final products (d'Astous and Legendre, 2009; Eckhardt et al., 2010).

Based on Eckhardt et al. (2010) and d'Astous and Legendre's (2009) works, consumers have three main reasons for justifying companies' unethical behavior in the market: (i) the reality of economic development, (ii) government dependency, and (iii) economic rationalization. The economic

\footnotetext{
${ }^{1}$ Besides consumer reasons for justifying brands' unethical behavior, previous research investigated the respective roles of consumer demographics, such as gender and age in consumers' reactions to product-harm crises (Laufer and Gillespie, 2004; Silvera et al., 2012). This research's findings show that women more often than men blame companies for productharm crisis, and that older adults focus less on the negative information associated with a crisis, and are thus less likely to incorporate this negative information into their attitudes and preferences.
} 
development argument includes the rationalization that macro-level economic development can only come about with a certain degree of unethical corporation behavior. Based on this rationale, consumers believe that a country's economic development fully justifies unethical behavior in the market (e.g., environmental degradation is the price to pay for economic development). Consumers believe that there is a trade-off between economic development and ethical issues (i.e., social and environmental issues may impede economic development), but that ethical and moral aspirations are less important than a country's economic development. The government dependency argument, on the other hand, refers to the belief that institutions, such as the government, are responsible for ethically regulating what (and how) products can be sold. Consumers reason that if there are no laws regulating social actors' misconduct, their behavior is legal, and it is not justifiable to blame them for it. Finally, the economic rationalization argument claims that price and other material attributes are more important in economic exchanges than ethical attributes ("it is all about costs and benefits," d'Astous and Legendre, 2009, p. 257), because consumers want the maximum value for their money, regardless of their ethical beliefs. Consistent with the conceptualization of attributions of blame and the role that prior beliefs play, consumers may activate their pre-existing beliefs even if they have clear information about the harm that a brand's use of toxic chemicals causes. Thus, once activated, such beliefs can influence consumers' assessment of the culpability of a brand's misconduct. Hence, we hypothesize that (see Figure 1):

H3: After exposure to an NGO campaign, consumer evaluation of brand blame is significantly higher when the intensity of the reasons for justifying a brand's unethical behavior is lower.

\subsection{The moderating effect of a brand's compliance with the NGO's campaign}

In previous sections, we argued that consumer attribution of blame negatively affects consumer attitudes towards the faulty brand and subsequent purchase intentions (Klein and Dawar, 2004). In this 
section we show how the brand's decision to comply with an NGO campaign can moderate this relationship.

NGO campaigns tend to use denunciatory tactics (Balsiger, 2010; 2014) to promote ethical practices in the market (i.e., reducing toxic chemicals in manufacturing processes and final products) (Chen et al., 2014; Thorpe, 1994; 2011). Using such tactics means accusing brands of misconduct (i.e., publicly reporting a company's misconduct), demanding remedial actions (i.e., offering the company at fault a chance to accept the NGO's requests and eliminate the source of the problem), and inviting consumers to make a "green, ethical, and/or conscious choice" when making buying decisions by evaluating (and reacting to) the company's behavior (i.e., they invite consumers to refrain from purchasing the brand if the brand decides not to comply with the campaign's requests).

Brand responses fall into two main categories (Brennan and Merkl-Davies, 2014; Brennan et al., 2013). Brands may choose to respond positively to the demand for remedial actions, thus adopting a conciliatory stance by accepting the accusation of misconduct and combining this with apologies and promises to remedy the problems. On the other hand, brands may decide to ignore, or even dispute, the misconduct charge, adopting a defensive orientation by denying the charge or providing excuses for it. Consequently, NGOs respond to brands that decide to comply with the campaign by rewarding them. Such rewards may also affect consumer reactions positively.

Moreover, brands' commitment to changing their practices is similar to a confession post-crisis communication strategy. The company admits having committed a negative act, accepts responsibility for this, includes an apology, and promises not to engage in such misconduct in the future (voluntary compliance, Siomkos and Kurzbard, 1994). In the psychology and management literature there is a fair amount of experimental and observational research (e.g., Gold and Weiner, 2000; Grappi and Romani, 2015; Weiner et al., 1991) showing that confessions are effective in reducing individual negative perceptions, as well as undesirable emotional and behavioral reactions. Thus, for brands that do not 
comply with an NGO campaign's requests, there could be a penalty, in consumer development terms, of less positive attitudes towards the brands. Hence, we hypothesize that (see Figure 1):

H4: The negative effect of consumer evaluation of brand blame on consumer attitudes towards a brand is greater if the brand does not comply with the NGO campaign.

—Insert Figure 1 approximately here-

\section{Materials and methods}

\subsection{The context: the NGO Detox campaign}

To test our hypotheses, the research collected respondent reactions to the Detox campaign, which involves several leading fashion brands (Greenpeace, 2011b). The Detox campaign, which Greenpeace launched globally in July 2011 and is still in progress, exposes the direct causal links between fashion brand manufacturing and toxic water pollution around the world. Greenpeace investigations in the manufacturing countries, and the testing of branded clothes for traces of hazardous chemicals, found that several fashion brands were polluting the environment and exposing their customers to risks related to the chemical agents in their clothes. The Detox campaign mobilizes thousands of people around the world, through petitions and special events of protest, to challenge major fashion brands to eliminate all hazardous chemicals from their supply chains and products. In Italy, the Detox campaign envisaged multiple actions throughout the country such as i) signing petitions (e.g., http://detox-outdoor.org/it-IT/petition/), ii) broadcasting viral campaigns and contents on social media endorsed by Italian celebrities (e.g., "the Fashion duel" https://www.youtube.com/watch?v=dVLsZ-ogEpE), and iii) organizing flash mobs and special events of protest (e.g., in February 2014 Greenpeace activists occupied Galleria Vittorio Emanuele during the "Fashion week" in Milan to demand toxic-free fashion). 
Due to the Detox campaign, some brands agreed to commit to eliminating all releases of hazardous chemicals throughout their entire global supply chain and products by 2020; other brands did not, even though they were implicated in the scandal (Greenpeace, 2011b; 2016).

\subsection{Questionnaire design}

The survey respondents were asked to read the scenario describing the Detox campaign and answer the questions that followed. To test hypotheses, four fashion brands involved in the Detox campaign (i.e., Armani, Burberry, Valentino, and Versace) were selected. Thus there were four different scenarios, one for each of the four selected brands. All the other information in the scenarios remained the same, with the exception of the brands' responses to the NGO's campaign. At the time of the data collection, out of the four brands two (i.e., Burberry and Valentino) agreed to detoxify their productions, the other two brands (i.e., Armani and Versace) did not. The inclusion of multiple brands in each case improves the validity of the results by preventing a single brand from influencing the results, thus ensuring greater reliability. Each participant responded to only one of the four different versions of the questionnaire. The questionnaire took approximately 15 minutes to complete.

\subsection{Respondents and Procedures}

Three different interviewers approached potential respondents personally as they shopped in an Italian mall in the Florence area that specializes in fashion brands (http://www.themall.it/it/outlettoscana/homepage.html). During March and April 2014, the interviewers approached 432 individuals, of whom c.96\% agreed to participate in the survey. Of these participants, c. $3 \%$ were disqualified for incorrectly remembering the brand reaction to the campaign checked in the final section of the questionnaire. Of the 403 remaining questionnaires, only those that the respondents had completed in full (c.92\%) were kept. Of the final sample of 370 consumers, c.47\% were men (c.f., census percentage according to Statistics Italy for 2012: 49\% [www.istat.it]); c.29\% of the respondents (c.f., $16 \%$ census) were between 18 and 29 years of age, $41 \%$ (c.f., $36 \%$ census) were between 30 and 49 years of age, 
$30 \%$ (c.f., $48 \%$ census) were over 50 years of age. Respondents with a high school education accounted for $31 \%$ (c.f., $41 \%$ census) of the sample, those with a lower level of education accounted for $23 \%$ (cf. $43 \%$ census), the rest were undergraduate or post-graduate respondents. Overall, the sample is relatively representative of the entire Italian adult population as regards the main demographic characteristics (sample error $\pm 5.1 \%$ with a $95 \%$ confidence level; $\mathrm{p}=\mathrm{q}=0.5$ ).

\subsection{Measures}

Measures composed of multiple items drawn from the extant literature were used to measure the constructs under investigation. An Italian marketing professor translated the English-language questionnaire into Italian, and two bilingual English-Italian speakers then back-translated and refined the translation.

D'Astous and Legendre's (2009) consumer-reasons-for-unethical-behavior scale (CRUB) was adapted to measure the intensity of a consumer's reasons for justifying brands' unethical behavior in the market. Consumers rated the answers on seven-point Likert scales (1="strongly disagree", $7=$ "strongly agree"). Table 1 shows details of items used for this scale. Consumers' perception of the severity of the toxic chemical scandal was measured by adapting Laufer et al.'s (2005) three-item, seven-point Likert scales (1="not at all", 7= "very much"). Table 2 shows details of items used for this

scale. Consumer evaluations of brand blame - the degree to which consumers perceive the brand to be responsible for the toxic chemical incident reported by the Detox campaign — were measured using Klein and Dawar's (2004) four-item seven-point Likert scale (1= "not at all”, 7 = "very much") (see Table 2). Goldsmith et al.'s (2001) three-item, seven-point Likert scale (1 = "totally disagree", $7=$ "totally agree") measured consumer attitudes towards the brand involved in the scandal; that is, the degree to which consumers perceive the brand to be good, favorable, and positive (see Table 2). Finally, consumers' intentions to purchase the faulty brand in the near future were measured using 
three-item seven-point Likert scale (1 = "not at all”, 7 = "very much"), which were adapted from Grappi et al. (2015) (Table 2).

This study also included three variables as covariate controls. The respondents' familiarity with the brand was measured by asking them to rate how familiar they were with the brand detailed in the scenario on a seven-point Likert scale $(M=4.38 ; \mathrm{SD}=1.58)$. The frequency of purchasing fashion brands was measured by asking the respondents to rate how often during the previous year they had bought fashion brands on a seven-point scale (from $1=$ never, to $7=$ at least once a month) $(\mathrm{M}=5.14$; $\mathrm{SD}=1.17$ ). The third variable, which controls for the possible effect of the specific brands, is considered in the study.

Finally, the brand reaction to the NGO campaign was verified in the final section of the questionnaire where respondents were asked to recall and write down whether the brand complied with the campaign's requests or not. We retained only the questionnaires where participants remembered the brand reaction to the campaign correctly.

\section{Data analysis and results}

\subsection{Measurement assessment}

Before testing the hypothesized effects of the structural model, we assessed the validity and reliability of the measurement model. First, since the scale "consumer reasons for justifying a brand's unethical behavior" included three sub-dimensions (i.e., "reality of economic development", “government dependency", and "economic rationalization"), we preliminarily tested whether these subdimensions could be organized hierarchically in a second-order confirmatory factor analysis (CFA) model. Results are reported in Table 1 . The model fits well: $\chi^{2}(132)=432.02$, RMSEA $=.08, \mathrm{SRMR}=$ $.04, \mathrm{CFI}=.98$ and NNFI $=.98$ (Appendix A). The 18-factor loadings on the first-order factors range from .63 to .89; the factor loadings relating the higher-order factor to the first-order factors range from .67 to .94 and are all statistically significant $(p<.01)$. All the average variances extracted are above the 
recommended threshold of .50 (Table 1). Given the satisfactory model fit and the very high factor loadings, it was possible to create a single measure for the variables as the mean value of the three firstorder factors.

- Insert Table 1 approximately here-

Second, we ran a CFA for our model measures. The fit indices are adequate: $\chi^{2}(94)=361.82$, RMSEA $=.08, \mathrm{SRMR}=.06, \mathrm{CFI}=.98$ and NNFI $=.97($ Appendix A). Table 2 shows that all standardized item loadings significantly load onto their constructs $(p<.01)$, and the standardized factor loadings are all greater than .60. Cronbach's alphas are all greater than .70, the composite reliability (CR) for these constructs is always greater than .60, and their AVE is always greater than .50.

Discriminant validity is also confirmed, as the shared variance between pairs of factors is always less than the corresponding AVE. Correlations between the components range from -.12 to .69. These findings combined show that the hypothesized measurement model is valid and reliable.

-Table 2 approximately here-

\subsection{Model assessment}

The data analysis applies the Hayes (2013) procedure to compute the conditional indirect effects. Figure 1 shows the model of the effect of an independent variable (the perceived severity of the toxic chemical scandal reported by the Detox campaign) $X$ on consumer attitudes towards the faulty brand $\left(Y_{1}\right)$ - and the subsequent influence of brand attitude on consumer intention to purchase the faulty brand in the near future $\left(Y_{2}\right)$ - where a mediator $M$ (consumer evaluations of brand blame) influences the effect, and a first moderator $W$ (consumer reasons for justifying brands' unethical behavior in the market) conditions the effects of $X$ on $M$. Simultaneously, a second moderator, $V$ (brand compliance with the campaign) conditions the effect of $M$ on $Y_{1}$. The level of respondent familiarity 
with the brand, the purchase frequency of fashion brands, and the specific brand to which each respondent was exposed are covariate controls ${ }^{2}$.

Table 3 presents the findings. Under the mediator variable model, the perceived severity of the toxic chemical scandal reported by the Detox campaign and the consumer reasons for justifying unethical behaviors interact significantly to influence consumer evaluations of brand blame $(b=.11, t=$ 2.92). The effect of the evaluation of the toxic chemical scandal caused by the brand on brand blame is higher when the intensity of consumer reasons for justifying brands' unethical behavior in the market is low, supporting H3. Under the outcome variable model, consumer evaluations of brand blame and brand compliance with the NGO campaign interact significantly $(b=-.18, t=-4.15)$ in affecting consumer attitudes towards the brand. The negative effect of consumer evaluations of brand blame on consumer attitudes towards the brand is greater if the brand did not comply with the campaign. In other words, the higher the consumer evaluations of the brand blame, together with the lack of brand compliance with the campaign, the lower the consumer attitudes towards the brand, which supports H4. Moreover, the three covariate controls did not affect the mediator or the dependent variable. The exceptions were the respondents' level of familiarity with the brand, which influenced the dependent variable, and the brand to which respondents were exposed in the scenario, which influenced the mediator (see Table 3). This means that the influences affecting attitude towards the brand are

\footnotetext{
${ }^{2}$ The possible effects of the respondents' demographic characteristics on the relevant variables of the model were controlled. Consumer attitudes towards the brand did not differ significantly in age $(F(2,367)=.15, p=.86)$, level of education $(F(3,366)=1.63, p=.18)$, or gender $(t(368)=.85, \mathrm{p}=.39)$. Consumer evaluations of brand blame did not differ significantly in age $(F(2,367)=.77, p=.46)$, level of education $(F(3,366)=2.50, p=.06)$, and gender $(t(368)=.87, \mathrm{p}=$ $.40)$. Consumer intentions to purchase the brand did not differ significantly in age $(F(2,367)=.03, p=.97)$, level of education $(F(3,366)=2.10, p=.10)$, and gender $(t(368)=.89, \mathrm{p}=.41)$.
} 
triggered, even taking into account the role played by the control variables, thereby strengthening the results.

Given the significant interactions between the moderators and the mediator, it is worth examining the conditional indirect effects on values of the moderators (see Table 4). Given that the paths of the mediation model are moderated, this means that the indirect effect will also be moderated. Results were then evaluated at three levels of the first moderator, that is, consumer reasons for justifying brands' unethical behavior in the market (low, mid, and high), and at two levels of the second moderator, that is, brand compliance with the campaign (brand compliance and no brand compliance). A confidence interval was generated at each level of the proposed moderators. Given that none of the confidence intervals contain zero at $\alpha=.05$, it can be concluded that all the conditional indirect effects are significant. Thus, in our model, consumer evaluation of brand blame turned out to be a significant mediator between the consumer-perceived severity of the toxic chemical scandal reported by the Detox campaign and the consumer attitude toward the brand, supporting H1. This mediating effect can be considered a universal process, as its indirect effect varied as a function of the proposed moderators but is still verified for all the different moderators' levels.

Finally, the hypothesized relation between attitude towards the brand and consumer intention to purchase the faulty brand was assessed by considering the correlation between these two variables $(\mathrm{r}=$ $.69 ; \mathrm{p}<.001)$. This result provides evidence of the connection between the two variables, which supports $\mathrm{H} 2$.

—Insert Table 3 and Table 4 approximately here-

\section{General discussion}

\subsection{Theoretical contribution}

This study investigates the role of NGOs in mobilizing consumers in order to achieve changes in a company's unethical practices, and at the same time examines the potential negative effects of an 
NGO campaign on the brands involved. Specifically, this study develops a conceptual model of consumer evaluations and reactions to NGO campaigns, which aim at changing brand manufacturing practices by means of consumer blame and consumer attitudes towards whichever brand the campaign focuses upon.

Taking the fashion industry as the empirical context of this study, this research develops and tests a model whereby the consumer-perceived severity of the toxic chemical scandal reported by the NGO campaign (i.e., the Dirty Laundry scandal) affects consumer attitudes towards the fashion brand, and the extent to which the consumer blame of the fashion brand at fault mediates this relationship. Two moderator variables regulate this mediation mechanism further: (1) the intensity of the reasons consumers use for justifying a brand's unethical behavior in the fashion industry, and (2) the decision of the fashion brand to comply (or not comply) with the campaign (i.e., to detoxify or not detoxify its manufacturing). The results show that the less consumers are inclined to justify a brand's unethical behavior in the market, the higher the consumer evaluations of the brand's blame. Moreover, the higher the consumer evaluations of the brand's blame, together with the lack of brand compliance with the campaign, the lower the positive consumer attitudes towards the brand and, consequently, the intention to purchase the brand in the future is lower. Finally, the results reveal a positive effect of brand familiarity on consumer attitudes towards the faulty brand. This effect reveals additional specific circumstances under which the proposed mechanisms underlying consumer responses to an NGO campaign can be better detailed. These deserve to be examined in depth in future studies.

This research makes theoretical contributions by developing and testing new mechanisms regarding consumers' responses to a brand's unethical behavior once these consumers have been exposed to public NGO campaigns aimed at promoting a company's behavior change and to the ensuing company responses. Generally, extant literature on this topic has analyzed consumer responses to negative publicity (e.g., Chatzidakis and Lee, 2013) separately from corporate response strategies to 
serious accusations (e.g., Brennan et al., 2013; Laufer and Coombs, 2006). By contrast, this study advances the research available by integrating these two separate streams of literature. It proposes a model that not only examines the role of NGO campaigns in influencing consumer evaluations of the brands on which the campaign focused, but also considers how company responses interact with the NGO campaign's accusations.

Furthermore, extant literature has widely analyzed the effects that attributions of blame have on consumer responses to the products, brands, and companies when involved in a very serious, negative event such as a product harm crisis (Klein and Dawar, 2004). This study contributes to the literature on this topic by confirming the pivotal role of consumer blame once independent NGO campaigns have exposed consumers to negative information about a brand, especially if such NGOs use denunciatory tactics, such as public shaming of a brand, rather than supportive tactics (Balsiger, 2010, 2014; O'Rourke, 2005). The study also introduces two moderating variables - namely (1) consumer reasons for justifying brands' unethical behavior in the market and (2) companies' response strategy - in order to highlight the conditions that enhance or reduce the strength of the relationships between the perceived severity of the toxic chemical scandal reported by the NGO's campaign, the blame, and the consumer responses. In the development of the proposed model, these moderating variables behave differently to provide an articulated, comprehensive view of how consumers react to NGOs campaigns, thus extending the contributions of Eckhardt et al. (2010) and d'Astous and Legendre (2009) on the one hand, and Gold and Weiner (2000) and Weiner et al. (1991) on the other.

\subsection{Managerial implications}

Rising numbers of shoppers now believe that it is unacceptable to charge high prices for clothing without a guarantee that it has been manufactured fairly and responsibly. NGOs increasingly call on fashion brands to be responsible for their operations' social and environmental impact. These campaigns' criticisms often question consumers' choices, asking them to what extent they are willing 
to satisfy their discretionary desires by buying irresponsible fashion brands. In this industry, consumers strongly perceive the conflict between fashion brands' satisfying discretionary desires and the irresponsible behavior of the selfsame fashion companies. Consumers are therefore increasingly looking for "guilt-free desires", a trend that favors consumers adhering to NGOs' campaigns that emphasize environmental and social respect.

Greenpeace's Detox campaign, investigated in this research, represents a relevant example of this trend. This campaign mobilized hundreds of thousands of people around the world to challenge major clothing brands to eliminate all releases of hazardous chemicals from their supply chains and products. In response to this activism, some brands committed themselves to detoxify their productions, while other brands did not (Greenpeace, 2011b; 2016). Our findings confirm that the strategic decision of the companies involved to comply with the Detox campaign is the most effective way to minimize negative consumer responses. From a broader perspective, this action can be compared to a confession post-crisis communication strategy, which can decrease losses and preserve the relationship with consumers and customers. These findings show that managers and practitioners can address the risk of a public NGO campaign by adopting the most effective strategy available; that is, they can accept responsibility, apologize, and promise not to engage in such unethical actions in the future. As an example, Burberry and Valentino, the two brands involved in this study that committed to detoxify their productions after Greenpeace accusations, are now in the middle of implementing their plan of hazardous chemical elimination for the deadline of 2020. Greenpeace rewarded these brands by publicly depicting their commitment as "credible", "ambitious", and as a "fabulous first step", thus enhancing their brand reputation (Greenpeace, 2013).

In general, as part of the strategy of compliance with the Detox campaign, companies decide to participate in cleaner production programs in partnership with suppliers, retailers and environmental experts which aim to reduce the environmental impact of garment and textile productions. The 
commitment to detoxify can stimulate virtuous initiatives focused on new approaches to eliminate chemicals from products and supply chains. This is already happening in Italy, where a collaboration which began in the Prato region now has 42 companies working together to detoxify the textile industry (https://secured-

static.greenpeace.org//international/Global/international/code/2016/Catwalk2016/pdf/Collaboration_Pr ato_ZDHC_2016.pdf). This ecological thinking related to the implementation of the Detox commitment can represent both an interesting starting point for the fashion industry to move toward more sustainable innovative business models, and at the same time an interesting best practice for other industries (Chen et al., 2014). The recent "Not just tuna" Greenpeace campaign (http://tuna.greenpeace.org/\#) is a further example of how an NGO campaign affects consumer demands, and brands' decisions to abandon destructive and irresponsible practices (i.e., overexploiting fishing methods) in favor of more sustainable ones.

Finally, our findings also have interesting insights for NGOs. For example, results confirm the opportunity for NGOs to direct their efforts at consumers with a lower predisposition to justify unethical behavior, in order to obtain returns as quickly as possible. This will help disseminate the NGO campaign effectively through the market by means of "less tolerant" consumers and thus attract the remaining "mainstream" consumers" attention. NGOs could therefore take advantage of "green" activists' engagement through involving these consumers in special events of protest and in co-creating the campaign contents, so as to promote a rapid diffusion of their campaign in the market.

\subsection{Limitations and further research}

This study has a number of limitations and opportunities for future research. Firstly, the use of survey allows a partial assessment of consumers' beliefs about a given research issue. Future studies could verify whether the results of this research hold good across different modes of data collection. 
For example, experimental manipulation could help fully capture the complexity of the effects on consumer responses of an $\mathrm{NGO}$ campaign in a more controlled environment.

Secondly, this research analyzed a specific NGO campaign in the fashion industry and considered four specific brands. Future research is invited to test the proposed model in different industries and using different brands to examine whether the effects of the mediating and the moderating variables show the same intensity in other empirical contexts. Such a finding would strengthen the external validity of these results.

Thirdly, future studies should also examine in greater depth the role that potentially important variables play in explaining consumer responses to NGO campaigns, to better delineate their influence on such responses. In recognition of the effect on consumer blame caused by the control variable's identifying the specific brands used in the study and, more generally, by the importance of the consumer-brand relationship, further research should analyze the following: namely, the possible effects that specific consumer-brand relationship characteristics (e.g. brand identification, brand loyalty, brand trust) may have on consumer responses to NGO campaigns and, consequently, on brand evaluations.

Finally, future research could examine consumers' different reactions to NGO campaigns communicated by different communication tools (e.g., testimonials, media, statements) to identify the most effective communication strategy to increase consumer evaluations of brand blame and, subsequently, consumer reactions. This will help NGOs manage their campaigns by maximizing consumer responses and promoting ethical behavior changes in consumers and companies.

\subsection{Conclusion}

Do NGO campaigns, aimed at denouncing brands' irresponsible practices, affect consumer evaluations and purchasing behaviors significantly? Can companies mitigate, and eventually take advantage, of such campaigns? Using the Dirty Laundry scandal and the Detox campaign as the 
empirical context of investigation, this research answers these questions. Yes, NGO campaigns significantly influence consumers' judgments of blame and their subsequent evaluations and purchasing behaviors towards the brands involved in toxic chemical scandals. Companies should not underrate NGO campaigns, especially when their consumer target is composed of "green" or "ethical" consumers, who are less inclined to consider the economic and political reasons behind a company's unethical practices. And, yes, the "faulty" brands, despite the negative effects of NGO denouncing campaigns, can still reduce, and even challenge, these negative effects by committing to eliminating the cause of the scandal by detoxifying the fashion productions. This post-crisis communication strategy represents a successful and beneficial solution for both the company itself, because the NGO can publicly award the company efforts and restore the company credibility, and society at large, because society can benefit from a less polluting environment. 


\section{References}

Balsiger, P. 2014. Between shaming corporations and promoting alternatives: The politics of an “ethical shopping map”. Journal of Consumer Culture, 14 (2), 218-235.

Balsiger P. 2010. Making political consumers: The tactical action repertoire of a campaign for clean clothes. Social Movement Studies: Journal of Social, Cultural and Political Protest, 9 (3), 311-329.

Brennan, N. M., Merkl-Davies, D. M. 2014. Rhetoric and argument in social and environmental reporting: the Dirty Laundry case. Accounting, Auditing \& Accountability Journal, 27 (4), 602-633.

Brennan, N. M., Merkl-Davies, D. M., Beelitz, A. 2013. Dialogism in corporate social responsibility communications: Conceptualizing verbal interaction between organizations and their audiences. Journal of Business Ethics, 115 (4), 665-679.

Brewer, M. B. 1977. An information-processing approach to attribution of responsibility. Journal of Experimental Social Psychology, 13 (1), 58-69.

Burger, J. M. 1981. Motivational biases in the attribution of responsibility for an accident. A metaanalysis of the defensive-attribution hypothesis. Psychological Bulletin, 90 (3), 496-512.

Chatzidakis, A., Lee, M. S. 2013. Anti-consumption as the study of reasons against. Journal of Macromarketing, 33 (3), 190-203.

Chen, T., Larsson, A., \& Mark-Herbert, C. (2014). Implementing a collective code of conductCSC9000T in Chinese textile industry. Journal of Cleaner Production, 74, 35-43.

d'Astous, A., Legendre, A. 2009. Understanding consumers' ethical justifications: a scale for appraising consumers' reasons for not behaving ethically. Journal of Business Ethics, 87 (2), 255268.

DeJoy, D. M., Klippel, J. A. 1984. Attributing responsibility for alcohol-related near-miss accidents. Journal of Safety Research, 15 (3), 107-115. 
Den Hond, F., De Bakker, F. G. 2007. Ideologically motivated activism: How activist groups influence corporate social change activities. Academy of Management Review, 32 (3), 901-924.

Eckhardt, G. M., Belk, R., Devinney, T. M. 2010. Why don't consumers consume ethically? Journal of Consumer Behaviour, 9 (6), 426-436.

Festinger, L. 1957. A theory of cognitive dissonance. Row, Peterson, Evanston.

Folkes, V. S. 1988. Recent attribution research in consumer behavior: a review and new directions. Journal of Consumer Research, 14 (4), 548-565.

Forno, F., Ceccarini, L. 2006. From the street to the shops: The rise of new forms of political actions in Italy. South European Society and Politics, 11 (2), 197-222.

Gao, H., Knight, J. G., Zhang, H., Mather, D. 2013. Guilt by association: Heuristic risks for foreign brands during a product-harm crisis in China. Journal of Business Research, 66 (8), 1044-1051.

Gold, J. G., Weiner, B. 2000. Remorse, confession, group identity, and expectancies about repeating a transgression. Basic and Applied Social Psychology, 22 (4), 291-300.

Goldsmith, R.E., Lafferty, B.A., Newell, S.J. 2001. The impact of corporate credibility and celebrity credibility on consumer reaction to advertisements and brands. Journal of Advertising, 29 (3), 3054.

Grappi, S., Romani, S. 2015. Company post-crisis communication strategies and the psychological mechanism underlying consumer reactions. Journal of Public Relations Research, 27 (1), $22-45$.

Grappi, S., Romani, S., Bagozzi, R. P. 2015. Consumer stakeholder responses to reshoring strategies. Journal of the Academy of Marketing Science, 43 (4), 453-471.

Greenpeace 2011a. Dirty laundry. Unravelling the corporate connections to toxic water pollution in China. Available at: http://www.greenpeace.org/international/Global/international/publications/toxics/Water\%202011/dir ty-laundry-report.pdf. 
Greenpeace 2011b. The Detox campaign. Available at:

http://www.greenpeace.org/international/en/campaigns/detox/water/detox/intro/.

Greenpeace 2013. In Fashion Duel, Valentino proves 'Green' really is the new 'Black'. Available at: http://www.greenpeace.org/international/en/news/Blogs/makingwaves/fashion-duel/blog/43909/.

Greenpeace 2016. The journey towards a toxic-free future. Available at: http://www.greenpeace.org/international/en/campaigns/detox/timeline/.

Hayes, A. F. 2013. Introduction to mediation, moderation, and conditional process analysis: A regression-based approach. New York: Guilford Press.

Hoffmann, S., Hutter, K. 2012. Carrotmob as a new form of ethical consumption. The nature of the concept and avenues for future research. Journal of Consumer Policy, 35 (2), 215-236.

Institute of Public \& Environmental Affairs 2012. Cleaning up the Fashion Industry. Available at: http://www.ipe.org.cn/Upload/Report-Textiles-One-EN.pdf.

Jorgensen, B.K. 1994. Consumer reaction to company-related disasters: The effect of multiple versus single explanations. Advances in Consumer Research, 21 (1), 348-352.

Kelley, H. H., Michela, J. L. 1980. Attribution theory and research, in: Rosenzweig, M. R., Porter, L. W. (Eds.), Annual review of psychology, pp.457-501. Palo Alto, CA: Annual Reviews.

Klein, J. G., Dawar, N. 2004. Corporate social responsibility and consumers' attributions and brand evaluations in a product-harm crisis. International Journal of Research in Marketing, 21 (3), 203217.

Klein, J. G., Smith, N. G., John, A. 2004. Why we boycott: consumer motivations for boycott participation. Journal of Marketing, 68 (3), 92-109.

Laufer, D., Gillespie, K. 2004. Differences in consumer attributions of blame between men and women: the role of perceived vulnerability and empathic concern. Psychology and Marketing, 21 (2), 141-157. 
Laufer, D., Gillespie, K., McBride, B., Gonzalez, S. 2005. The role of severity in consumer attributions of blame: defensive attributions in product-harm crises in Mexico. Journal of International Consumer Marketing, 17 (2-3), 33-50.

Laufer, D., Coombs, W. T. 2006. How should a company respond to a product harm crisis? The role of corporate reputation and consumer-based cues. Business Horizons, 49 (5), 379-385.

Lin, C., Chen, S., Chiu, C., Lee, W. 2011. Understanding purchase intention during product-harm crises: Moderating effects of perceived corporate ability and corporate social responsibility. Journal of Business Ethics, 102, 455-471.

Lorek, S., Spangenberg, J. H. 2014. Sustainable consumption within a sustainable economy-beyond green growth and green economies. Journal of Cleaner Production, 63 (1), 33-44.

Micheletti, M. 2003. Political virtue and shopping: Individuals, consumerism, and collective action. New York: Palgrave.

Mont, O. , Plepys, A. 2008. Sustainable consumption progress: should we be proud or alarmed? Journal of Cleaner Production, 16 (4), 531-537.

O'Rourke, D. 2005. Market movements: Nongovernmental organization strategies to influence global production and consumption. Journal of Industrial Ecology, 9 (1-2), 115-128.

Robbennolt, J. 2000. Outcome severity and judgments of responsibility: A meta-analytic review. Journal of Applied Psychology, 30 (12), 2575-2609.

Sassatelli, R. 2006. Virtue, responsibility and consumer choice: Framing critical consumerism, in: Brewer, J., Trentmann, F. (Eds.), Consuming Cultures, Global Perspectives: Historical Trajectories Transnational Exchanges, Oxford: Berg, pp. 219-250.

Silvera, D. H., Meyer, T. M., Laufer, D. 2012. Age-related reactions to a product harm crisis. Journal of Consumer Marketing, 29 (4), 302-309. 
Siomkos, G. J., Kurzbard, G. 1994. The hidden crisis in product-harm crisis management. European Journal of Marketing, 28 (2), 30-41.

Smith, A.K., Bolton, R.N. 2002. The effect of customers' emotional responses to service failures on their recovery effort evaluations and satisfaction judgments. Journal of the Academy of Marketing Science, 30 (1), 5-23.

Stolle, D., Micheletti, M. 2013. Political consumerism: Global responsibility in action. NY: Cambridge University Press.

The Guardian. 2013. A sustainable model for fashion. Available at: http://www.theguardian.com/sustainable-business/sustainable-model-for-fashion.

The Guardian. 2011. Luxury brands must wake up to ethical and environmental responsibilities. Available at: http://www.theguardian.com/environment/green-living-blog/2011/sep/16/luxurybrands-ethical-environmental-fashion

Thorpe, B. 1994. The role of NGOs and the public to promote cleaner production. Journal of Cleaner Production, 2 (3), 153-162.

Thorpe, B. 2011. How the Toxics Use Reduction Act continues to promote clean production Internationally. Journal of Cleaner Production, 19 (5), 552-558.

Verbeke, W. 2001. Beliefs, attitude and behaviour towards fresh meat revisited after the Belgian dioxin crisis. Food Quality and Preference, 12 (8), 489-498.

Walster, E. 1966. Assignment of responsibility for an accident. Journal of Personality and Social Psychology, 3 (1), 73-79.

Weiner, B. 1986. An attributional theory of motivation and emotion, Springer Verlag, New York. Weiner, B., Graham, S., Peter, O., Zmuidinas, M. 1991. Public confession and forgiveness. Journal of Personality, 59 (2), 281-312. 
Table 1

Consumer reasons for justifying brands' unethical behavior in the market: Item list, CFA Factor loadings, Cronbach's Alpha, Average Variance Extracted

\begin{tabular}{|c|c|c|c|}
\hline & $\begin{array}{c}\text { Std. factor } \\
\text { loading }\end{array}$ & $\alpha$ & AVE \\
\hline \multicolumn{4}{|l|}{ FACTOR LOADINGS ON FIRST-ORDER FACTORS } \\
\hline Reality of economic development & & .91 & .59 \\
\hline $\begin{array}{l}\text { I do not boycott companies that are established in countries where labor is cheaper, because they contribute to the development of these countries' } \\
\text { economy. }\end{array}$ & $.77 * * *$ & & \\
\hline It is normal for developing countries to have companies that do not to respect the environment entirely; I will not boycott them for that. & $.80 * * *$ & & \\
\hline There is nothing wrong with buying products made by underpaid workers; this is the price to pay for the development of their country. & $.86^{* * *}$ & & \\
\hline $\begin{array}{l}\text { When I buy products made in poor countries, I do not worry about the working conditions in which they were made, because what counts is the economic } \\
\text { development of these countries. }\end{array}$ & $.73 * * *$ & & \\
\hline I believe that companies' lack of respect for the environment is a necessary evil to encourage a country's economic growth. & $.63 * * *$ & & \\
\hline I do not blame companies for their non-ecological behavior, because the economic development of their country requires that they act like this. & $.82 * * *$ & & \\
\hline I understand that growing companies engage in non-socially responsible actions because this is the natural way of doing things. & $.77 * * *$ & & \\
\hline Government dependency & & .92 & .68 \\
\hline $\begin{array}{l}\text { Non-ecological products are not dangerous, because if they were the government would not allow companies to use ingredients that are harmful to the } \\
\text { environment. }\end{array}$ & $.71 * * *$ & & \\
\hline $\begin{array}{l}\text { I would not change my buying habits in order to be more ecological, because it is the government's role to force companies to conform to environmental } \\
\text { standards. }\end{array}$ & $.81 * * *$ & & \\
\hline $\begin{array}{l}\text { I do not have to feel bad when buying products made by underpaid workers; after all, it is up to the government to force companies to pay their workers } \\
\text { adequately. }\end{array}$ & $.84 * * *$ & & \\
\hline As long as the government does not provide environmental guidelines, I consider that there is nothing wrong with buying non-ecological products. & $.88 * * *$ & & \\
\hline I would not refrain from buying products made by underpaid workers given that their selling is authorized by the government. & $.83^{* * *}$ & & \\
\hline Non-ecological products are not really dangerous for the environment, because if they were the government would prohibit them. & $.84 * * *$ & & \\
\hline Economic rationalization & & .91 & .67 \\
\hline If I compare the price of a product and the fact that it is ecological, I lean naturally towards the price. & $.77 * * *$ & & \\
\hline I am willing to buy products made by underpaid workers if they are less expensive. & $.88^{* * *}$ & & \\
\hline I have no problem with buying counterfeit products, because I find that the price of real brands is excessive. & $.89 * * *$ & & \\
\hline I pay more attention to the price of products that I buy than to their ecological and/or ethical aspects. & $.69 * * *$ & & \\
\hline I prefer to buy counterfeit products at very low prices than buying real brands at an excessive price. & $.87 * * *$ & & \\
\hline \multicolumn{4}{|l|}{ FACTOR LOADINGS ON THE SECOND-ORDER FACTOR } \\
\hline Reality of economic development on the second-order factor & $.86^{* * *}$ & & \\
\hline Government dependency on the second-order factor & $.94 * * *$ & & \\
\hline Economic rationalization on the second-order factor & $.67 * * *$ & & \\
\hline
\end{tabular}

Notes: $\alpha=$ Cronbach's alpha; AVE $=$ Average variance extracted; $* * * p<.001$ 
Table 2

Model variables: Item list, Mean, Standard deviation, CFA Factor loadings, Cronbach's Alpha, Composite reliability, Average Variance Extracted

\begin{tabular}{|c|c|c|c|c|c|c|}
\hline & M & $\mathrm{SD}$ & $\begin{array}{c}\text { Std. } \\
\text { factor } \\
\text { loading }\end{array}$ & $\alpha$ & $\mathrm{CR}$ & AVE \\
\hline Consumer perceptions of the severity of the toxic chemical scandal & 5.14 & 1.45 & & .83 & .83 & .61. \\
\hline I consider severe the effects of the toxic chemical scandal reported by the Detox campaign & & & $.75 * * *$ & & & \\
\hline I consider dangerous the effects of the toxic chemical scandal reported by the Detox campaign & & & $.79 * * *$ & & & \\
\hline I consider harmful the effects of the toxic chemical scandal reported by the Detox campaign & & & $.83^{* * *}$ & & & \\
\hline Consumer reasons for justifying brands' unethical behavior in the market & 2.53 & 1.09 & & .82 & .84 & .64 \\
\hline Reality of economic development on the second-order factor & & & $.87 * * *$ & & & \\
\hline Government dependency on the second-order factor & & & $.88 * * *$ & & & \\
\hline Economic rationalization on the second-order factor & & & $.62 * * *$ & & & \\
\hline Consumer evaluations of brand blame & 5.25 & 1.33 & & .92 & .92 & .75 \\
\hline I blame the brand for the chemical scandal reported by the Detox campaign & & & $.82 * * *$ & & & \\
\hline In my opinion, the brand is responsible for the chemical scandal reported by the Detox campaign & & & $.72 * * *$ & & & \\
\hline In my opinion, the brand is accountable for the chemical scandal reported by the Detox campaign & & & $.97 * * *$ & & & \\
\hline The chemical scandal reported by the Detox campaign is the fault of the brand & & & $.94 * * *$ & & & \\
\hline Consumer attitudes towards the brand involved in the toxic chemical scandal & 3.40 & 1.39 & & .94 & .95 & .86 \\
\hline I perceive the brand to be good & & & $.91^{* * *}$ & & & \\
\hline I perceive the brand to be favorable & & & $.91 * * *$ & & & \\
\hline I perceive the brand to be positive & & & $.94 * * *$ & & & \\
\hline Consumer intentions to purchase the faulty brand in the near future & 2.73 & 1.48 & & .97 & .86 & 69 \\
\hline I intend to buy this brand in the near future & & & $.88^{* * *}$ & & & \\
\hline I intend to purchase this brand in the near future & & & $.65 * * *$ & & & \\
\hline I will buy this brand in the near future & & & $.92 * * *$ & & & \\
\hline
\end{tabular}

Notes: $\mathrm{M}=$ Mean; $\mathrm{SD}=$ Standard deviation; $\mathrm{Std}=$ Standardized; $\alpha=$ Cronbach's alpha; $\mathrm{CR}=$ Composite reliability; AVE $=$ Average variance extracted; $* * *$ if $\mathrm{p}<.001$ 
Table 3

\section{Results}

\begin{tabular}{|c|c|c|}
\hline \multirow[t]{2}{*}{ MEDIATOR VARIABLE MODEL } & \multicolumn{2}{|c|}{$\mathrm{M}=$ Consumer evaluation of brand blame } \\
\hline & $\mathrm{b}$ & $\mathrm{t}$ \\
\hline $\begin{array}{l}\text { X: perceived severity of the toxic chemical scandal reported by the Detox } \\
\text { campaign }\end{array}$ & .26 & $6.01 * * *$ \\
\hline W: consumer reasons for justifying brands' unethical behavior in the market &.- .35 & $-5.58 * * *$ \\
\hline $\mathrm{X} * \mathrm{~W}$ & .11 & $2.92 *$ \\
\hline C: purchase frequency of fashion brands & .08 & 1.44 \\
\hline C: consumer familiarity with the brand & -.03 & -.62 \\
\hline C: brand to which respondents were exposed & .13 & $2.15^{*}$ \\
\hline \multirow{2}{*}{ OUTCOME VARIABLE MODEL } & \multicolumn{2}{|c|}{ Y1 = Attitude towards the brand } \\
\hline & $\mathrm{b}$ & $\mathrm{t}$ \\
\hline M: consumer evaluation of brand blame & -.49 & $-10.33 * * *$ \\
\hline $\begin{array}{l}\text { X: perceived severity of the toxic chemical scandal reported by the Detox } \\
\text { campaign }\end{array}$ & -.001 & -.02 \\
\hline $\mathrm{V}$ : brand compliance with the campaign & -.34 & $-2.52 *$ \\
\hline $\mathrm{M} * \mathrm{~V}$ & -.18 & $-4.15^{* * *}$ \\
\hline C: purchase frequency of fashion brands & -.05 & -.98 \\
\hline $\mathrm{C}$ : consumer familiarity with the brand & .18 & $4.51 * * *$ \\
\hline C: brand to which respondents were exposed & .07 & .60 \\
\hline \multicolumn{3}{|l|}{ Direct effect of $\mathrm{X}$ on $\mathrm{Y}$} \\
\hline Effect & & \\
\hline \multirow[t]{2}{*}{-.001} & & .98 \\
\hline & \multicolumn{2}{|c|}{ R-square $=.40$} \\
\hline
\end{tabular}

$*$ if $\mathrm{p}<.05 ; * *$ if $\mathrm{p}<.01 ; * * *$ if $\mathrm{p}<.001 . \mathrm{W}$ and $\mathrm{V}=$ moderator, $\mathrm{M}=$ mediator, $\mathrm{X}=$ manipulation, $\mathrm{Y}=$ outcome variable, $\mathrm{C}=$ control variable. PROCESS model \# 21 . 
Table 4

Conditional indirect effects of $X$ (perceived severity of the toxic chemical scandal reported by the Detox campaign) on Y (Attitude towards the brand) on the values of the moderators

\begin{tabular}{|c|c|c|c|c|c|}
\hline \multicolumn{6}{|c|}{ Bootstrap 95\% confidence intervals for conditional indirect effect - bias corrected and accelerated (BCa) } \\
\hline Mediator (M) & $\begin{array}{l}\text { Moderator } 1(\mathrm{~W}) \text { : } \\
\text { Consumer reasons for justifying } \\
\text { brands' unethical behavior in the } \\
\text { market }\end{array}$ & $\begin{array}{l}\text { Moderator } 2(\mathrm{~V}) \text { : } \\
\text { Brand compliance } \\
\text { with the campaign }\end{array}$ & $\begin{array}{l}\text { Conditional indirect effects on Y } \\
\text { (Attitudes towards the brand) }\end{array}$ & Lower & Upper \\
\hline \multirow{6}{*}{$\begin{array}{l}\text { Consumer } \\
\text { evaluation of } \\
\text { brand blame }\end{array}$} & \multirow{2}{*}{ Low } & No compliance & -.10 & -.18 & -.03 \\
\hline & & Compliance & -.05 & -.10 & -.01 \\
\hline & \multirow{2}{*}{ Mid } & No compliance & -.17 & -.24 & -.11 \\
\hline & & Compliance & -.08 & -.13 & -.04 \\
\hline & \multirow{2}{*}{ High } & No compliance & -.25 & -.34 & -.16 \\
\hline & & Compliance & -.11 & -.19 & -.06 \\
\hline
\end{tabular}

$\mathrm{W}$ and $\mathrm{V}=$ moderator, $\mathrm{M}=$ mediator, $\mathrm{Y}=$ dependent variable. 


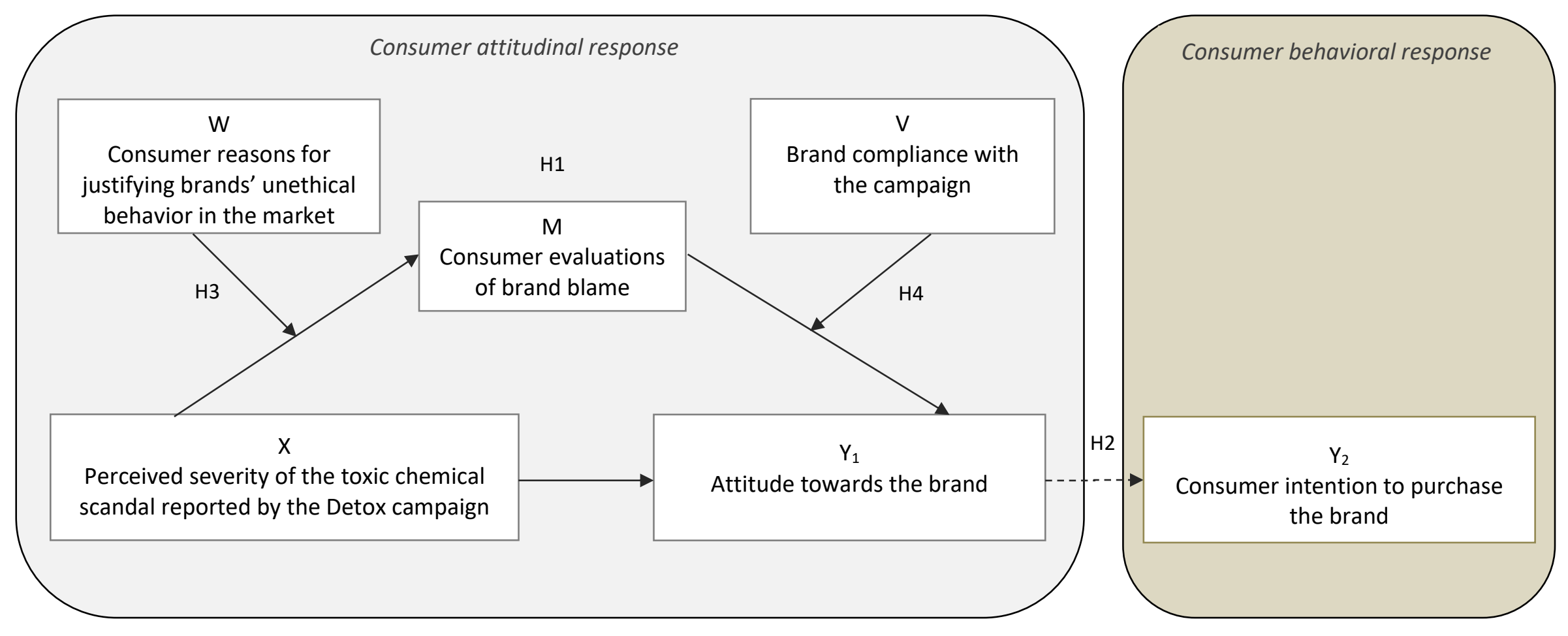

Figure 1

Model and Hypotheses 


\section{Appendix A}

\section{Cross reference table}

\begin{tabular}{|c|c|c|}
\hline Acronym & Full name & Explanation \\
\hline$\chi^{2} / \mathrm{df}$ & $\begin{array}{l}\text { Relative (or normed) } \\
\text { chi-square }\end{array}$ & $\begin{array}{l}\text { This index measures the fit of the model and equals the chi-square index divided by the degrees of } \\
\text { freedom. Acceptable ratio for this statistic range from zero to } 3 \text {. However, since relative chi-square } \\
\text { is sensitive to sample size, other measures of fit have been developed. }\end{array}$ \\
\hline RMSEA & $\begin{array}{l}\text { Root mean square error } \\
\text { of approximation }\end{array}$ & $\begin{array}{l}\text { This index measures the fit of the model and tells us how well the model, with unknown but } \\
\text { optimally chosen parameter estimates, would fit the populations covariance matrix. A RMSEA } \\
\text { lower or equal to } .08 \text { shows a good fit. }\end{array}$ \\
\hline SRMR & $\begin{array}{l}\text { Standardized root mean } \\
\text { square residual }\end{array}$ & $\begin{array}{l}\text { This index measures the fit of the model and indicates the standardized square root of the difference } \\
\text { between the residuals of the sample covariance matrix and the hypothesised covariance model. Well } \\
\text { fitting models obtain SRMR values lower than } .05 \text {. However, SRMR values as high as. } 08 \text { are } \\
\text { deemed acceptable. }\end{array}$ \\
\hline CFI & Comparative fit index & $\begin{array}{l}\text { This index analyzes the model fit by examining the discrepancy between the data and the } \\
\text { hypothesized model, while adjusting for the issues of sample size inherent in the chi-squared test of } \\
\text { model fit, and the normed fit index. CFI values range from } 0 \text { to } 1 \text {, with larger values indicating } \\
\text { better fit. CFI values equal or greater than } .95 \text { generally indicate a good model fit. }\end{array}$ \\
\hline NNFI & Non-Normed Fit Index & $\begin{array}{l}\text { This index measures the fit of the model and assesses the model by comparing the } \chi 2 \text { value of the } \\
\text { model to the } \chi 2 \text { of the null model. The null/independence model is the worst case scenario as it } \\
\text { specifies that all measured variables are uncorrelated. Values for this statistic range between } 0 \text { and } 1 \\
\text { with values equal or greater than } .95 \text { indicating a good fit. }\end{array}$ \\
\hline$\alpha$ & Cronbach's alpha & $\begin{array}{l}\text { This coefficient is used as a lower bound estimate of the internal consistency or reliability of a scale. } \\
\text { It assumes that the average correlation of a set of items is an accurate estimate of the average } \\
\text { correlation of all items that pertain to a certain construct. Values of } \alpha \text { equal or greater than } .70 \text { are } \\
\text { acceptable. }\end{array}$ \\
\hline CR & Composite reliability & $\begin{array}{l}\text { This coefficient is an estimate of the convergent validity of the measurement model. Values of CR } \\
\text { equal or greater than } .70 \text { are acceptable. }\end{array}$ \\
\hline AVE & $\begin{array}{l}\text { Average variance } \\
\text { extracted }\end{array}$ & $\begin{array}{l}\text { This coefficient is an estimate of the convergent validity of the measurement model. This coefficient } \\
\text { measures the amount of variance that is captured by the construct in relation to the amount of } \\
\text { variance due to measurement error. If the AVE is less than .50, then the variance due to } \\
\text { measurement error is greater than the variance due to the construct. In this case, the convergent } \\
\text { validity of the construct is questionable. }\end{array}$ \\
\hline
\end{tabular}

